Article

\title{
The Empire in the Provinces: The Case of Carinthia
}

\author{
Helmut Konrad \\ Institut für Geschichte, Karl-Franzens-Universität Graz, Attemsgasse 8/II, [505] 8010 Graz, Austria; \\ helmut.konrad@uni-graz.at
}

Academic Editors: Malachi Hacohen and Peter Iver Kaufman

Received: 16 May 2016; Accepted: 1 August 2016; Published: 5 August 2016

\begin{abstract}
This article examines the legacy of the Habsburg Monarchy in the First Austrian Republic, both in the capital, Vienna, and in the province of Carinthia. It concludes that Social Democracy, often cited as one of the six ingredients that held the old Empire together, took on distinct forms in the Republic's different federal states. The scholarly literature on the post-1918 "heritage" of the Monarchy therefore needs to move beyond monolithic generalizations and toward regionally focused comparative studies.
\end{abstract}

Keywords: empire; socialism; Jews; Habsburg Monarchy; Austria; Vienna; Carinthia; German Nationalism; Sprachenkampf

\section{Introduction}

Which forms did the ideas take that allowed the Habsburg monarchy to persist, despite the diversity of nationalisms present in the small Republic of German-Austria, for so long after the end of the First World War? What was the "glue" that held this multiethnic empire together, when its collapse had been predicted since 1848, and which of its elements continued to exist beyond 1918? How was this heritage expressed in the different regions of the new republic?

At least six factors can be identified as ingredients of the "glue" that held the monarchy together: first, the Emperor, a figure who symbolized the fusion of the complex linguistic, ethnic and religious components of the Habsburg state; second, the administrative officials, who were loyal to the Emperor and worked in the ubiquitous and even architecturally similar buildings of the Monarchy's district authorities and train stations; third, the army, whose members promoted the imperial ideals through their long terms of service and acknowledged linguistic diversity. The army and the administrative officials had a strong aristocratic component, but were pledged to serve the socially diverse nation. Fourth, there were political movements of internationalism such as that of the Social Democrats, who intellectually dominated the discourse on political transformation and thus the continual efforts to save the monarchy. Fifth, the Catholic Church, owing to its alliance with the throne, acted as a pillar of support for the Monarchy. Sixth, the Empire's Jewish population constituted an additional cohesive element. On this topic, Malachi Hacohen recently wrote: "Jews were the only ethnic group to adopt enthusiastically the official Staatsgedanke, the Austrian imperial idea, the ideology of dynastic patriotism. Poor Galician traditionalists and refined Viennese assimilationists, orthodox rabbis and liberal scholars, Zionists and socialists, all declared their loyalty to the supra-national empire" [1]. Which of these six factors still existed in November of 1918? As the Emperor's body was borne to his grave in 1916, the idea of the empire and its associated loyalties were also symbolically bid farewell. The administrative officials as well as the army attempted, in part out of sheer necessity, to form alliances with the new rulers of the various successor states. The Social Democrats called for an "Austrian revolution" in their name and watched as their internationalist movements were curtailed not only in Hungary and Bavaria, but also in Czechoslovakia, the Kingdom of Yugoslavia and Italy. Catholicism was still practiced, albeit to different degrees in the different regions. For the Austrian Jews, the "Kingdom of Grace" had vanished. 
Members of my generation were still assigned 3 November 1918, by the Austrian author Franz Theodor Csokor, as required reading in middle school [2]. A not entirely unintentional product of the corporate state, Csokor's development of the characters was based on his dream of the Monarchy, and the play was first performed in 1937 at the Burgtheater. In a sanatorium in Carinthia's Karavankas Mountains, a group of soldiers lives out the last days of the war and together observes its military end. The colonel, who symbolizes the empire, commits suicide as the monarchy falls. At his grave, the lower-ranking officers each toss one shovel of earth on to the coffin, saying: "earth from Hungary", "earth from Carinthia", "earth from Poland", "earth from Slovenia", "earth from Bohemia", and "earth from Rome". Only the Jewish regimental doctor, whose dream of the Monarchy has not yet faded, hesitates and then says: "earth from Austria".

Csokor portrayed "Austria", conceptualized as a supranational empire, as living on in the figure of the Jewish doctor. This concept should, at least in part, newly manifest itself through the idea of a "second, better German state" in the Ständestaat: Catholic, but not openly hostile toward other religions, and, in recognition of the merits of the pre-existing army, symbolized through the construction of a crypt (the Heldendenkmal) north of the outer gate (Äußere Burgtor) in Vienna. The thrilling history of its creation, and the various political messages it conveys, was only recently discovered. Wilhelm Frass, who created the epitaph, hid a capsule inside it that contained a message with German nationalist—in fact, Nazi-sentiments, to which his assistant secretly added a significantly pacifist, left-wing addendum [3]. The monument and its two hidden messages illustrate the wide range of the political spectrum at the time.

For the Jews, the disintegration of the Habsburg Monarchy into numerous small nation-states was a terrible shock. A cultural milieu that was strongly influenced by Judaism continued to thrive in the cities of Vienna and Prague, and also to some extent in other major cities, which contributed to significant advances made at the universities and the awarding of several Nobel Prizes. Literature, music and theater, in addition to the main newspapers, all kept "The World of Yesterday" alive [4]. In particular, urbane manners were still practiced in the cities' coffee houses. Nationality restrictions proved fertile ground, however, for the growth of anti-Semitism.

Even in the supposed model of a modern city, in Vienna, which was given the nickname "Red Vienna" (Rotes Wien) due to the majority rule of the Social Democrats, questions of citizenship were rigidly dealt with and reference was made to the so-called "National Law" (Heimatrecht) in other parts of the former monarchy. The number of Jews was perceived to be a threat, and the Social Democratic Party, which was the logical political party of choice for a good part of the Jewish population, did not want to be labeled as the "Jewish party". Thus, the party attempted to present a secular appearance and, like Julius Deutsch, spasmodically distanced itself from the Jewish religion [5].

Deutsch was an absolutely typical example of the party line taken by the Austrian Social Democrats after 1918. They addressed the question of Jewish identity by equating the process of modernization with assimilation and absorption into an enlightened socialist society. Both the concept of the traditional Jewish community and the Zionist position of the struggle for a modern Jewish nation were rejected. The assumption was that their absorption into the German culture and language, following the tradition of 1848 , and the ultimate Austrian revolution would make such issues of identity obsolete.

For many Jews living in Vienna, the issue of their Heimatrecht became a crucial concern following the establishment of the First Republic of Austria. Jakob Kellmann, whose memoirs, now stored in the Leo Baeck Institute in New York, were dedicated to his daughter on the occasion of her birthday in 1940 in Panama, exemplifies this ([5], p. 186f). A native of Galicia, who had already successfully integrated in Vienna and been decorated for his military service several times during World War I, Kellmann was denied his Heimatrecht by Interior Minister Leopold Waber, a prominent member of the anti-Semitic Großdeutsche Volkspartei (Greater German People's Party), on the grounds that he "didn't belong to the German race" ([5], p. 186f). To add insult to injury, Albert Sever, the social democrat who would become Lower Austria's first governor, also served Mr. Kellmann (as he did thousands of other 
Jews) with an order of expulsion, citing the need "to maintain public order" ([5], p. 186f). While the denial of Heimatrecht was, from a legal perspective, in most cases justified, it must also be recognized that Waber and Sever's actions were based in racist arguments.

Even in Vienna, then, the situation was highly problematic. It would be misguided to argue the position taken by Arthur Schnitzler, and recently cited by Lisa Silverman, that the Jews of Vienna enjoyed a pleasant environment in the interwar period. Silverman states: "...there was little evidence to suggest that anti-Semitism, either casual or violent, would prevent Jews who sought to immerse themselves in Austrian culture from doing so" [6]. The anti-Semitic movement was often associated with the labor movement and frequently coupled with hostility toward intellectuals and prejudices regarding economic status. The gaps between the (unionized) base and the leaders of the political party, as well as the gap between the editorial staff of the newspapers favored by the working class and Der Kampf, would create problems and become perhaps the Achilles' heel of Viennese Social Democracy during the final years of the First Republic of Austria.

In any case, it is also striking that theorists adhering to Marxism-led by members of the Social Democratic Workers' Party of Austria from 1918 onward-lost sight of the main challenges facing them due to the complexity of the question of nationalism. The issue had been settled in the great works published during the pre-war period. Now, the revolutionary experiments related to "Red Vienna", the educational system, and the relations between farmers and the urban population were being conducted. The position on the issue of nationalism, declared in an addendum to the party platform, was fixed until at least 1933 and the rise to power of Hitler in Germany [7]. The Austrian Social Democratic Party disguised its German-nationalist position beneath the cloak of "modernization", which they wished to take advantage of in order to more quickly achieve a socialist society. Addressing the peculiarities singular to certain parts of Austria, the situation of minority groups, or even reacting to latent anti-Semitism expressed by members within their own ranks simply did not appear on the agenda.

\section{The Provinces}

Fascinated by the success of interwar Vienna's Social Democratic politicians, who skillfully combined their imperial heritage with modern social, educational, economic and political elements to form a working model, cultural historians-particularly those from outside Austria-have tended to focus too narrowly on the Austrian capital. This falls short of the mark.

The federal provinces, the borders of which were largely based on those of the previously existing crown lands (territories that had been acquired by the Austrian Habsburgs), offered the security of both a sense of continuity and a regional identity. Burgenland, for example, was formed from four counties in western Hungary and came under Austrian administration in autumn 1921. The lack of an Austrian national identity was replaced by "provincial consciousness" (Landesbewusstsein). It was the anthems and flags of Tyrol, Styria, Salzburg or Carinthia that evoked patriotic fervor, but at the provincial level. The state anthems were (and still are) sung with enthusiasm, and the attempts to create a national anthem, which were pitiful in comparison and never evoked much emotional response, are the subject of much cultural and historical research. Up until now (despite its centralist constitution and Austrian identity, which initially developed opportunistically as a result of the experiences with National Socialism, but which later became fixed), Austria's citizens have largely identified themselves with their province. Provincial governors have greater political power than the federal government, which is all too often made aware of this fact.

An especially interesting phenomenon is that of the "anti-Vienna reflex", which is noticeable in all provinces to varying degrees and based on different, even contradictory, reasons. This reflex is a reaction to the ideas of Vienna as a Moloch (money pit) and a cesspool, and as a response to the centralism of Vienna and its prejudice against the provinces. However, this reaction is also in opposition to the Red Vienna, the Jewish Vienna and the multicultural Vienna (it was called a "Babylon" by citizens of Graz during the later period of the monarchy). In addition, it is sometimes in reaction, 
oddly enough, to the Catholic Vienna and the Viennese archbishop, who represents the enemy in some crypto-Protestant provinces (Upper Austria and Carinthia).

These unique responses of the individual states are exemplified in Carinthia. I have chosen this province not because it has particularly outstanding peculiarities (one could just as easily select Vorarlberg, Tirol, Salzburg or Styria), but because choosing it provides me with the opportunity to refer to my own family history, which I can add here to the chain of argumentation.

Carinthia, Austria's southernmost province, had fallen economically behind as compared to other crown lands of the Habsburg monarchy in the late 19th century. The decline of the once-thriving mining industry started once the push for urbanization began. The unemployed miners went back to the farms that they, as second or third sons, had left for a life in industry. Members of the large rural underclass population had often also gained industrial experience and, therefore, allied themselves with the Social Democratic political party. Agricultural laborers and railway workers formed the electorate of the Social Democrats, which attained no less than $49 \%$ of the vote in 1919. In this way, a "Red Carinthia" was established that lacked a true intellectual component. The various German nationalist groups, which especially dominated among the provincial elites (i.e., doctors, notaries and teachers), together made up $40 \%$, so that the Christian Social Party was even weaker in Carinthia than in Vienna [8].

The Christian Socials' low level of popular support can be explained as a function of the Counter-Reformation, which could never be fully enacted against a crypto-Protestant movement, and as a reaction to the role that the Catholic Church historically played in defending the country's Slovenian-speaking minority. The fight over the language(s) used in local villages took place between the Catholic priests and the German nationalist or social democratic teachers. The latter, however, could apply more economic pressure, for example by influencing decisions about who received loans from regional banks, and more psychological pressure, by arguing the superiority of the "German culture" over that of the "Slavic". The number of people who spoke up for the minority, therefore, declined dramatically after the turn of the century. While German-speaking elites existed, most of whom had studied in Graz, there was no Slovenian-speaking university in the Habsburg Monarchy prior to 1918, which in part explains the delayed nationalization process of the Carinthian Slovenians.

As historian Hellwig Valentin writes: "The Social Democrats represented progress in the German-speaking world at the time, while expressed commitment to the national Slovenes was equated with a clerical-reactionary position" [8]. Thus, the Social Democratic Party's internationalist movement was confined in Carinthia to a greater Germanic perspective. Yes, it was possible to cross borders, but only in the direction of Germany, and crossing the language barrier was considered unacceptable. In this way, the transition between social democracy and German nationalism was eased.

Anti-Semitism was a topic of discussion, but not a dominant one. The population of the Jewish community was simply too small. In 1910, 210 members of the Jewish religious community were counted in Klagenfurt, and the first successful attempt to effect an organizational separation from the religious community in Graz took place in 1923 [9]. In total, the number of Carinthian Jews reached only approximately 300. In 1910, 311 Jewish inhabitants of Carinthia were counted, while in 1934, the number stood at 269. Thus, it was neither the number of Jews nor the question of the Heimatrecht and citizenship that was crucial, but rather anti-Semitism, which, closely linked to German nationalism and anchored in the worldview of the Social Democratic Party, had its roots in a mixture of anti-liberal, ideological, biologistic, economic and anti-intellectual ideas, all directed against the country's capital. The bogeyman of the "Jew" was effective virtually without any Jews present. It was a shadow enemy.

After 1918, the Carinthian Social Democrats made considerable efforts not to be associated with the "Jewish" party leaders in Vienna. "We are German...we are Aryans, not Jews," said Social Democratic Party delegate August Neutzler in October 1919 during the provisional Carinthian assembly ([10], p. 578). The strategy taken was to equate capitalism with Judaism. The anti-capitalist politics had two soapbox topics: Jewish assets and the anti-Semitic, German nationalist capitalists. No explanations were offered for this internal contradiction, but each topic probably served its purpose. 
What can one truly identify as part of the Imperial heritage in Carinthia? Little remains of the factors mentioned above, which held the Habsburg monarchy together. The imperial family was strongly Catholic and deeply rooted in Vienna; not even a traditional holiday (such as into the Salzkammergut region) tied it to Carinthia. The administrative officials and the army in Carinthia could barely be differentiated from those in the other crown or federal states. The Jewish population was too small and had little cultural influence, and the Social Democrats differed only in their constituencies and a few social demands related to German nationalism.

What remained as a legacy from the late monarchy was the so-called "language war" (Sprachenkampf)". After 1918, the national conflicts among members of the Danube monarchy who lived in Carinthia continued on a microcosmic level ([10], p. 402). The dispute over the border demarcation, which culminated in the bloody Carinthian "defensive battle" (Kärntner Abwehrkampf) and was finally determined in Austria's favor during a referendum held on 10 October 1920, stuck in the minds of members of the majority population for decades. These experiences primed them to interpret Yugoslavia, ruled by Tito, as a threat.

At that time, every second vote cast for an undivided Carinthia was cast by a person with Slovenian as their native language. The Slovenian population, which had not yet been touched by (language) nationalism, was concerned with issues of economism and markets for their agricultural products. They were also concerned about the question of military service for their sons, which had been obligatory in the Kingdom of Yugoslavia. They were not yet greatly concerned about language. However, that did not matter: the old cultural battle over the "language barrier", even with reference to symbols, was continually reenacted by the German-speaking population. An additional verse was added to the Carinthian anthem (its national anthem):

“Wo Mannesmut und Frauentreu

die Heimat sich erstritt aufs neu,

wo man mit Blut die Grenze schrieb

und frei in Not und Tod verblieb..."

["Where courageous men and loyal women

Fought for the renewed Homeland;

They drew the borders with their blood

And remained, in distress or dead, but free..."]

To be German meant to be a courageous man or faithful woman. To be Slovenian implied the opposite. German nationalism and social democracy demanded that the borders be drawn in blood, reinforcing the idea that borders were required, and shaped the province. The Catholic Church was the refuge of the Slovenians and, today in Lower Carinthia, cemetery gravestones and their inscriptions speak for themselves.

This exceptional Carinthian example can also be illustrated through a family history. My father, who was born in 1914, was one of two illegitimate children born to Rosa Konrad, a female worker on a farm near the town of Preitenegg in the Lavant Valley. As a child, he had watched as his mother was rejected from the Catholic Church because of the life she had led. This gifted child, stemming from the agricultural working class, gained entrance to the German nationalist educated middle class in the district town of Wolfsberg. As a member of an athletic association, my father was behind an effort to change the name of Sablatnig Lake, located in a bilingual region of the province, to "Turnersee", as it is called today. In this environment, the ideals of National Socialism fell on fertile ground, but my father was not allowed to pursue a career with the NS regime because his Aryan certificate (Ariernachweis) was incomplete (i.e., "father unknown"). While working on the war front in Narvik as a paramedic, he was a dedicated National Socialist, who quickly found his way into the Social Democratic Party in 1945. His adherence to the triad of German nationalism, social democracy and anti-clericalism did not 
allow him to interpret this choice as a breach of principle. Anti-Semitism was a clearly recognizable, though perhaps not pervasive, attitude.

Therefore, it is no coincidence that the Social Democrats positioned themselves in the province quite differently than they did in "Red Vienna" after 1918. "Red Carinthia" was located at the other end of the political spectrum. Although it may be tempting, given the unusually weak position of the Church in this province, to dismiss Carinthia as an "exceptional case", there is good reason to doubt whether a "normal" case can in fact be identified. Following the breakup of the Monarchy, all eight existing federal states (provinces), in addition to Vienna, went their own special way; radicals in the industrial regions of Styria or Upper Austria, anti-clericals in the Salzkammergut, German nationalists in Carinthia. The consequences of these internal differences were ultimately revealed in February 1934.

Conflicts of Interest: The author declares no conflict of interest.

\section{References and Notes}

1. Malachi Haim Hacohen. "Kosmopoliten in einer ethnonationalen Zeit? Juden und Österreicher in der Ersten Republik." In Das Werden der Ersten Republik:...der Rest ist Österreich. Edited by Helmut Konrad and Wolfgang Maderthaner. Wien: Gerold, 2008, vol. 1, p. 281.

2. Franz Theodor Csokor. 3. November 1918. Wien: Paul Zsolnay, 1936.

3. Heidemarie Uhl supervised and documented this discovery. ORF, ÖE1 Mittagsjournal, 10 July 2014.

4. Stefan Zweig. Die Welt von Gestern. Erinnerungen eines Europäers. Stockholm: Bermann-Fischer, 1942.

5. Julius Deutsch. Ein weiter Weg. Lebenserinnerungen. Wien: Amalthea, 1960.

6. Lisa Silverman. Becoming Austrians. Jews and Culture between the World Wars. Oxford: Oxford University Press, 2012, p. 4.

7. Helmut Konrad. Sozialdemokratie und "Anschluss". Historische Wurzeln, Anschluss 1918 und 1938, Nachwirkungen. Wien: Europaverlag, 1978.

8. Hellwig Valentin. "Kärnten—ein Sonderfall der österreichischen Zeitgeschichte." In Mapping Contemporary History. Zeitgeschichte im Diskurs. Edited by Margit Franz, Heimo Halbrainer, Gerald Lamprecht, Karin M. Schmidlechner, Eduard G. Staudinger, Monika Stromberger, Andrea Strutz, Werner Suppanz and Heidrun Zettelbauer. Wien: Böhlau, 2008, p. 404.

9. Charles Steiner. "Kärnten: Stumme Zeugen einer (fast) vergessenen Kultur." David Heft, 2014. Available online: http:// davidkultur.at/ausgabe.php?ausg=100\&artikel=944 (accessed on 2 August 2016).

10. Hellwig Valentin. Nationalismus oder Internationalismus? Arbeiterschaft und nationale Frage. Mit besonderer Berücksichtigung Kärntens 1918-1934. Klagenfurt: Verlag des Geschichtsvereines für Kärnten, 2000, vol. 2. 